\title{
PERMUKAAN ENERGI POTENSIAL HIDROGEN PADA SISTEM GRAFIT TERINTERKALASI INVESTIGASI TEORI FUNGSI KERAPATAN
}

\author{
Rahmat Gunawan ${ }^{1}$, Melanie David ${ }^{2}$, Hideaki Kasai ${ }^{2}$, Muhamad A. Martoprawiro $^{3}$, Cynthia L. Radiman ${ }^{3}$, \\ Hermawan K. Dipojono ${ }^{4}$ \\ ${ }^{1}$ Program Studi Kimia, Universitas Mulawarman, Samarinda 75123, Kalimantan Timur, Indonesia \\ ${ }^{2}$ Division of Precision Science and Technology and Applied Physics, Osaka University, Suita, Osaka, 565-0871, \\ Japan \\ ${ }^{3}$ Kelompok Keilmuan Kimia Fisik dan Anorganik, Institut Teknologi Bandung, Bandung 40132, Indonesia \\ ${ }^{4}$ Laboratorium Computational Material Design-Quantum Engineering, Institut Teknologi Bandung Bandung \\ 40132, Indonesia
}

Corresponding author: gunawan@fmipa.unmul.ac.id

\begin{abstract}
Abstrak
Permukaan energi potensial untuk sistem hidrogen pada permukaan grafit terinterkalasi alkali (Li, Na dan K) telah diteliti, secara teoritis. Model struktural, sifat energik, dan elektronik dari hidrogen pada sistem alkali/grafit dihitung melalui teori fungsi kerapatan (DFT) dengan menggunakan pendekatan koreksi-gradien Perdew-Burke-Ernzerhof (PBE). Perhitungan dilakukan dengan menggunakan basis set plane-wave, dan interaksi elektron-inti dijelaskan menggunakan pendekatan pseudopotential. Pada langkah pertama, permukaan energi potensial diperoleh dengan cara menghitung energi berbagai posisi molekul hidrogen pada permukaan grafit, yaitu di atas atom karbon (top), di atas ikatan C=C (bridge), dan di atas ring (hollow). Diperoleh hasil bahwa molekul hidrogen yang paling stabil adalah pada posisi top, dengan energi sebesar 3,2 eV pada jarak 0,019 A. Selanjutnya semua perhitungan dilakukan pada jarak 3,2 A dari permukaan grafit. Pada langkah berikutnya, permukaan energi potensial atom alkali ( $\mathrm{Li}, \mathrm{Na}$, dan $\mathrm{K}$ ) pada permukaan grafit memberi hasil bahwa atom alkali paling stabil pada posisi hollow dengan jarak antara $\mathrm{Li}, \mathrm{Na}$, dan $\mathrm{K}$ pada permukaan grafit adalah 1,7 A, 2,3 A, dan 2,6 A dengan energi minimum -1,37 eV, -0,66 eV dan -0,96 eV, secara berurutan. Dari data kerapatan muatan menunjukkan bahwa terjadi peningkatan transfer muatan elektron dari atom alkali terhadap orbital elektron pi grafit. Pada langkah terakhir, permukaan energi potensial minimum diperoleh pada variasi posisi hidrogen molekul pada sistem grafit terinterkalasi atom alkali, dan menunjukkan model permukaan energi potensial seperti yang ditunjukkan pada gambar di bawah. Diperoleh bahwa terdapat enam titik energi potensial terendah yang dapat ditempati oleh enem molekul hidrogen yaitu pada posisi bridge dari sistem ini. Jarak antara keenam molekul hidrogen dengan atom $\mathrm{Li}$, Na, dan atom $\mathrm{K}$ adalah 2,6 A, 2,7 A, dan 2,8 A, dengan energi minimum -0,082 eV, eV dan -0,071 -0,079 eV, secara berurutan. Hal ini menunjukkan bahwa kehadiran atom Li memberikan nilai kapasitas yang lebih tinggi dibandingkan dengan atom $\mathrm{Na}$ dan K. Hasil ini mendukung dan menjelaskan secara kualitatif adanya peningkatan kapasitas penyimpanan hidrogen dalam sistem alkali-grafit.
\end{abstract}

Keywords

Teori fungsi kerapatan, hidrogen, grafit terinterkalasi atom alkali

\section{Pendahuluan}

Krisis energi di dunia mengharuskan ilmuwan bekerja keras untuk dapat menciptakan konversi energi yang berkelanjutan [1]. Salah satu energi alternatif dari banyak energi alternatif yang cukup banyak diteliti oleh ilmuwan dalam beberapa tahun ini adalah energi hydrogen [2]. Hal ini karena diperkirakan bahwa energi hidrogen adalah energi yang dapat diperbaharui dan ramah lingkungan, dimana konversi energi hidrogen ini adalah melalui proses fuel cells [3].

Namun sisi kelemahan penelitian energi hidrogen $\left(\mathrm{H}_{2}\right)$ melalui proses fuel cells adalah masih berharga mahal dan belum mencapai hasil yang diharapkan [4]. Proses fuel cells sendiri adalah melalui tiga tahap utama yaitu penyimpanan gas $H_{2}$, penyaluran gas $H_{2}$, dan 
proses elektrokimia penghasil listrik dari gas $\mathrm{H}_{2}$ [5].

Penelitian dari ketiga tahap di atas masih terus dilakukan oleh berbagai pusat penelitian dunia, misal Department of Energy USA (DOE) menargetkan keberhasilan menciptaan materi penyimpan $\mathrm{H}_{2}$ pada tahun 2012 dengan kemampuan hingga 6,5\% berat materi [6].

Berbagai materi yang dijadikan kandidat sebagai materi penyimpan $\mathrm{H}_{2}$ adalah materi berbasis karbon, oksida logam dan senyawa organik pengasil gas $\mathrm{H}_{2}$ [7]. Salah satu materi berbasis karbon yang cukup melimpah di bumi termasuk di Indonesia, khususnya di pulau Kalimantan adalah grafit [8]. Karena grafit adalah tahap lanjutan dari bentuk batubara dalam sedimentasi hutan hingga jutaan tahun [9].

Penelitian grafit sebagai kandidat materi penyimpan $\mathrm{H}_{2}$ dimotori oleh Chambers dkk [10], secara eksperimen. Namun karena masih banyak fenomena yang belum terungkap khususnya interaksi antara molekul $\mathrm{H}_{2}$ dengan lapisan grafit, maka ilmuwan melanjutkan kajiannya dengan metode kimia komputasi dan simulasi. Jarak anta lapisan grafit yang hanya 3.35 A menghasilkan kapasitas penyimpan hidrogen yang relatif kecil [11].

Usaha ilmuwan dilanjutkan dengan cara memperbesar jarak antar lapisan grafit hingga kapasitas penyimpanan $\mathrm{H}_{2}$ menjadi lebih besar [12]. Penelitian perhitungan kuantum untuk masalah ini dimulai dengan berbagai cara mulai dengan dopping atau interkalasi oleh logam alkali [13], senyawa komplek [14], molekul $C_{60}$ [15], nanotube [16], dan lain-lain. Interkalasi terhadap grafit ini kemudia dikenal sebagai materi grafit terinterkalasi atau Graphite intercalated Compounds (GICs) [17].

Perbesaran kapasitas grafit dengan interkalasi logam dilakukan mulai loga alkali (Li, $\mathrm{Na}$, dan K), hingga $\mathrm{Ca}[18]^{18}$ dan $\mathrm{Mg}$ [19]. Secara perhitungan kuantum, GICs ini telah menghasilkan kapasitas penyimpanan $\mathrm{H}_{2}$ yang cukup signifikan.

Namun kajian tentang bagaimana model permukaan energi potensialnya masih belum dilakukan, sehingga belum mampu menjawab seberapa banyak maksimal molekul $\mathrm{H}_{2}$ yang teradsorpsi pada sistem GICs [20].

\section{Metodologi Penelitian}

Penentuan struktur elektron dan energi interaksi dihitung melalui Program PWScf/Quantum Espresso berbasis UNIX, dan visualisasi program perhitungan tersebut dilakukan melalui Program XCrysDen berbasis UNIX [21].

Penentuan fungsi energi potensial exchangecorrelation, dilakukan berdasarkan pendekatan metode generalized-gradient-corrected, PBE (Perdew-Burke-Ernzerhof) dengan potensial eksternal $400 \mathrm{eV}$ cutoff. Pemilihan pendekatan GGA-PBE ini adalah karena lebih akurat untuk sistem interaksi atom/molekul terhadap suatu permukaan padatan grafit dari batubara, bila dibandingkan dengan pendekatan lain [22].

Pemilihan persamaan orbital Kohn-Sham ditentukan dengan ekspansi orbital basis set plane wave untuk setiap atom-atom yang terlibat. Pemilihan konsep plane wave ini penting karena berkesuaian dengan model fase ruah dan permukaan grafit dari batubara [23].

Penentuan energi potensial untuk perhitungan interaksi antara elektron valensi atom, dengan pendekatan kurva Vanderbilt ultrasoft pseudopotential. Sifat struktur dari sistem periodik grafit dari batubara ditentukan dengan model grafit supersel $(4 \times 4)$, dan memakai $90 k$-points spesial, parameter Brillouin Zone (BZ) sampling (8x8x8) MonkhorstPack mesh, untuk semua interaksin dengan semua atom/molekul yang terlibat dalam perhitungannya. Hal ini karena model supersel ini dianggap lebih realistis dengan model eksperimen [24]. 

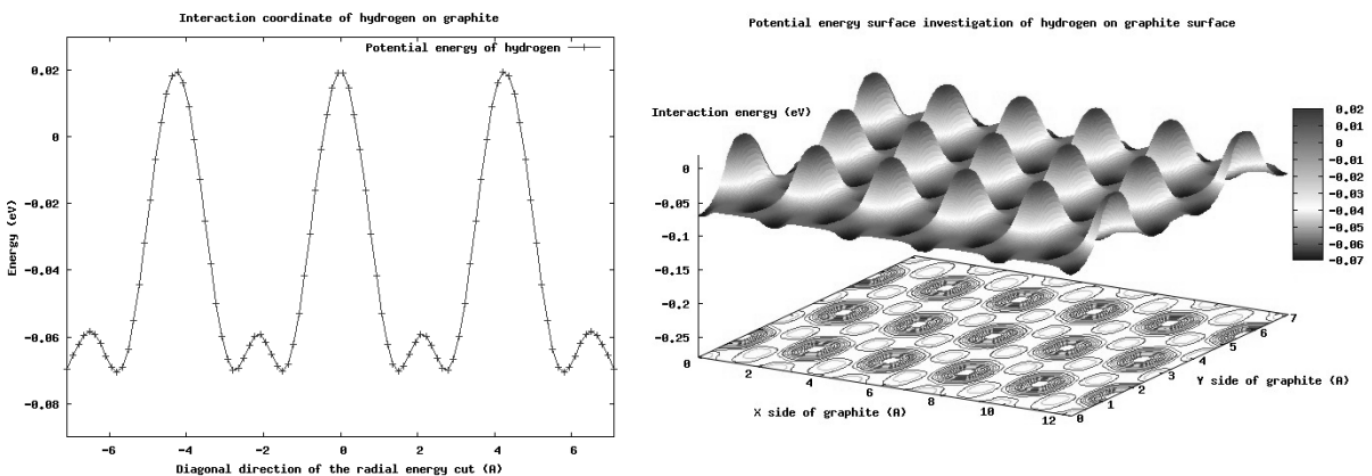

Gambar 1. Investigasi 2D dan 3D Permukaan energi potensial sistem $\mathrm{H}_{2}$-grafit.

\section{Results and Discussion/ Hasil dan Pembahasan}

Diperoleh hasil bahwa molekul hidrogen yang paling stabil adalah pada posisi top, dengan energi sebesar 3,2 eV pada jarak 0,019

A. Selanjutnya semua perhitungan dilakukan pada jarak 3,2 A dari permukaan grafit.

Pada langkah berikutnya, permukaan energi potensial atom alkali ( $\mathrm{Li}, \mathrm{Na}$, dan K) pada permukaan grafit memberi hasil bahwa atom alkali paling stabil pada posisi hollow dengan jarak antara $\mathrm{Li}, \mathrm{Na}$, dan $\mathrm{K}$ pada permukaan grafit adalah 1,7 A, 2,3 A, dan 2,6 A dengan energi minimum $-1,37 \mathrm{eV},-0,66 \mathrm{eV}$ dan -0,96 eV, secara berurutan. Pada Gambar 1. Meunjukkan profil Investigasi 2D dan 3D dari permukaan energi potensial sistem $\mathrm{H}_{2}$-grafit.

Dari data kerapatan muatan menunjukkan bahwa terjadi peningkatan transfer muatan elektron dari atom alkali terhadap orbital elektron pi grafit. Pada langkah terakhir, permukaan energi potensial minimum diperoleh pada variasi posisi hidrogen molekul pada sistem grafit terinterkalasi atom alkali, dan menunjukkan model permukaan energi potensial seperti yang ditunjukkan pada Gambar 2.

Diperoleh bahwa terdapat enam titik energi potensial terendah yang dapat ditempati oleh enem molekul hidrogen yaitu pada posisi bridge dari sistem ini. Jarak antara keenam molekul hidrogen dengan atom $\mathrm{Li}, \mathrm{Na}$, dan atom $\mathrm{K}$ adalah 2,6 A, 2,7 A, dan 2,8 A, dengan energi minimum $-0,082 \mathrm{eV}, \mathrm{eV}$ dan $-0,071-0,079 \mathrm{eV}$, secara berurutan.

Analisis energi pita elektron, rapat keadaan, dan beda rapat muatan, menunjukkan adanya peningkatan kontribusi orbital atom dari permukaan grafit ke molekul hidrogen, dan memunculkan sifat kebolehpolaran molekul $\mathrm{H}_{2}$ untuk model permukaan grafit dan tidak memunculkan sifat kebolehpolaran molekul $\mathrm{H}_{2}$ untuk model grafit dua lapis, Liaht Gambar 3.a.

Investigasi untuk interaksi atom alkali pada permukaan grafit memberikan hasil yang identik untuk setiap atom alkali yaitu stabil pada posisi hollow dari permukaan grafit sebesar $1.7 \mathrm{~A}, 2.3 \mathrm{~A}, 2.6 \mathrm{~A}$, dengan energi interaksi $-1.37 \mathrm{eV},-0.66 \mathrm{eV},-0.96 \mathrm{eV}$, untuk logam $\mathrm{Li}, \mathrm{Na}$ and $\mathrm{K}$, secara berturut-turut, Lihat pada Gambar 2.

Interaksi dan kontribusi orbital atom membentuk hibridisasi $2 s-$; $2 p$ - dan 3s- ; 3ppada daerah energi valensi dan hibridisasi $2 s-$ $*$; $2 p-{ }^{*}$ dan $3 s_{-}^{*}$; $3 p-*$ pada daerah konduksi untuk logam $\mathrm{Li}$ dan $\mathrm{Na}$, secara berturut-turut. Sedangkan pada logam K tidak melibatkan orbital $p$, sehingga hanya menghasilkan hibridisasi $4 s-$ dan $4 s-{ }^{*}$ pada daerah energi valensi dan konduksinya, lihat pada Gambar 3.b,c,d.

Perhitungan geometri relaksasi dan penentuan permukaan energi potensial untuk interaksi molekul $\mathrm{H}_{2}$ pada permukaan GICs dengan interkalat logam alkali ( $\mathrm{Li}, \mathrm{Na}$, dan K) 

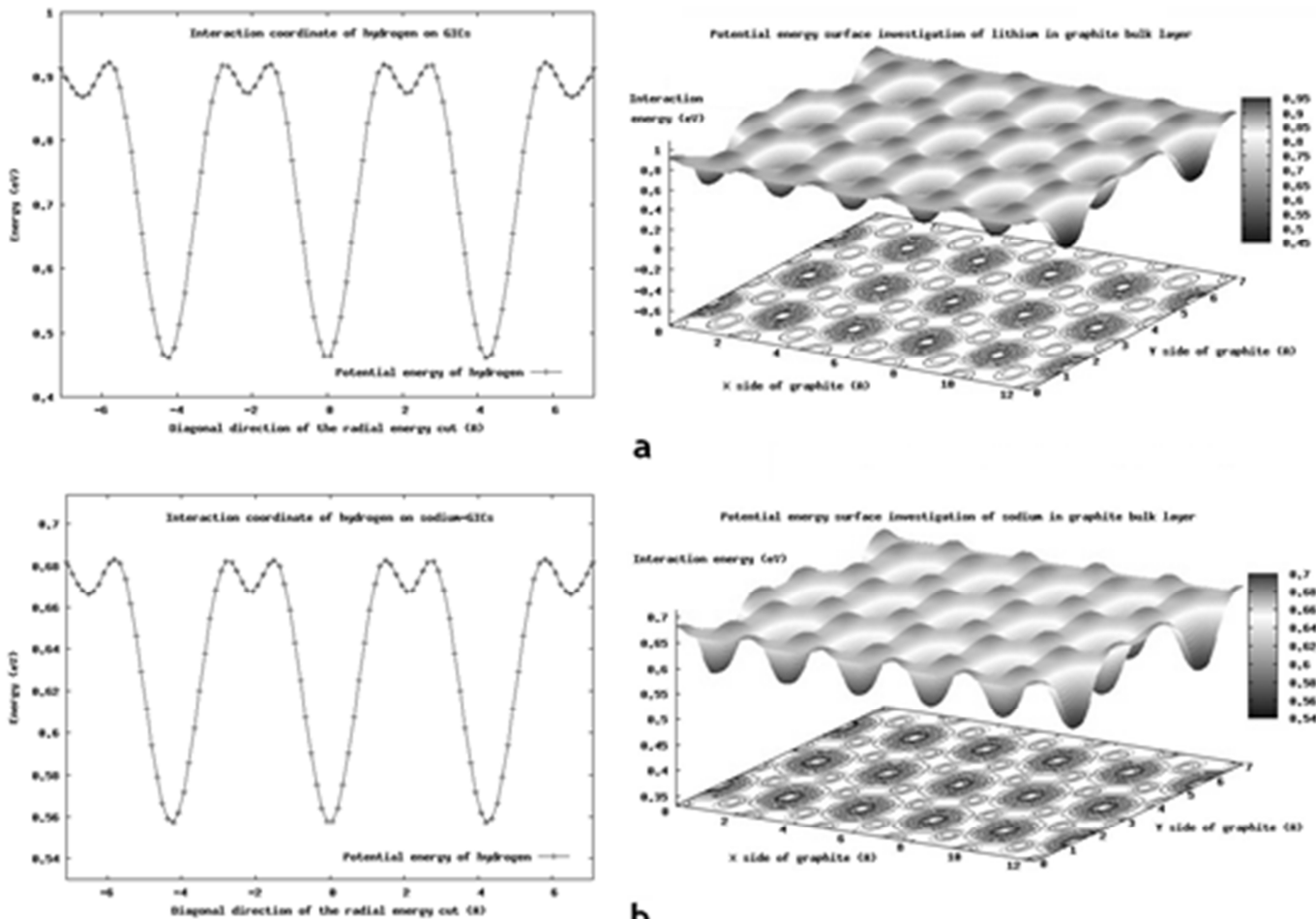

a
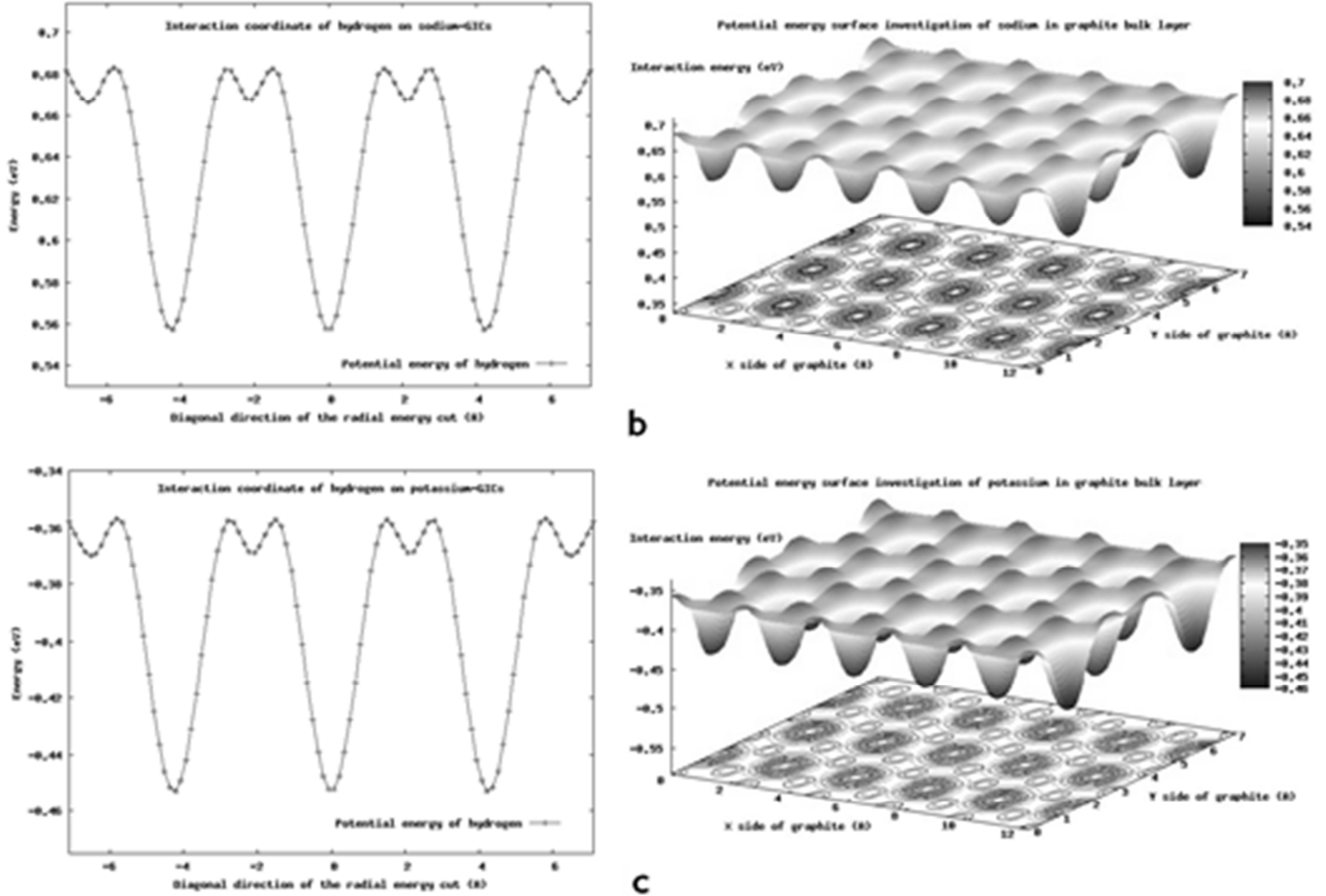

b

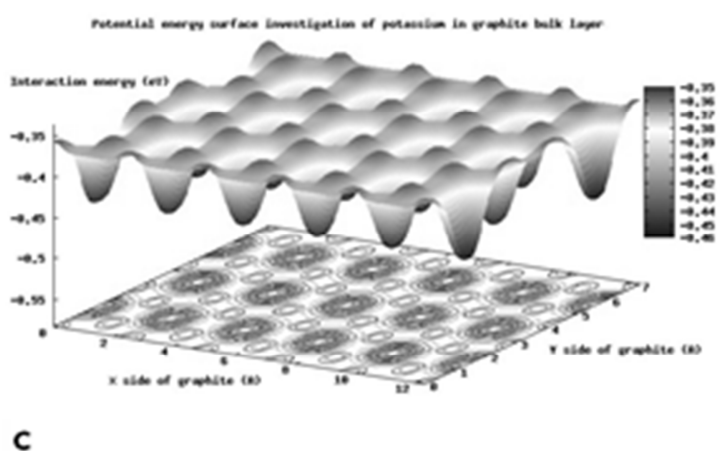

Gambar 2. Investigasi 2D dan 3D Permukaan energi potensial sistem (Li, Na, dan K)-grafit.
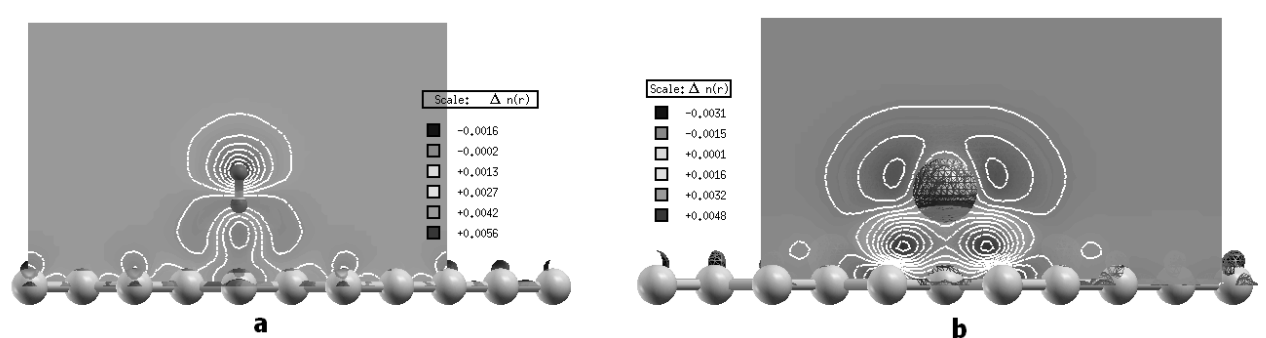

b
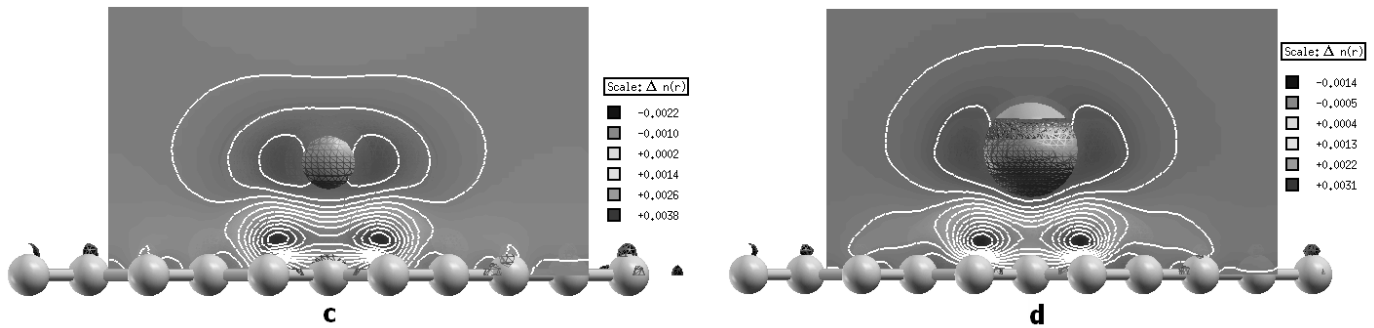

Gambar 3. Distribusi, elektron untuk sistem $\mathrm{H}_{2}$ dan ( $\mathrm{Li}$, Na, dan K)-grafit.

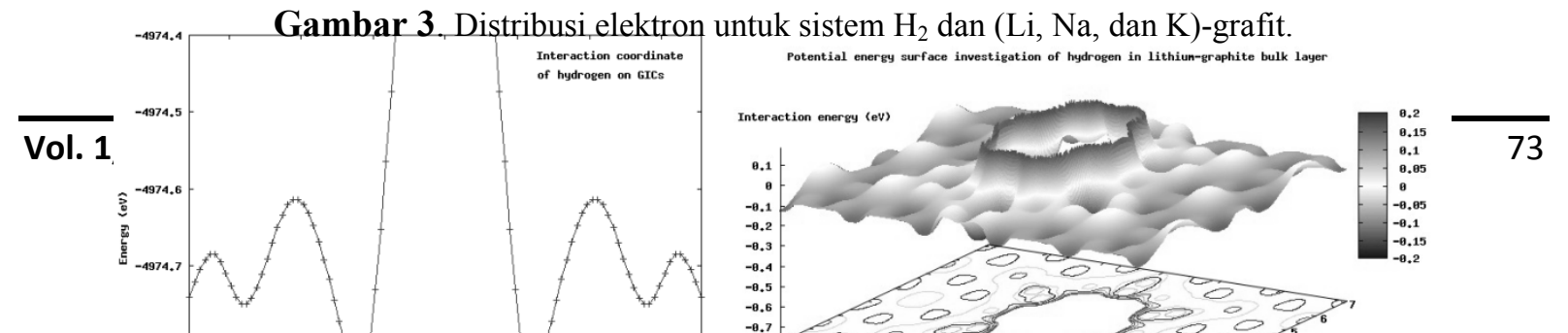


Gambar 4. Investigasi 2D dan 3D Permukaan energi potensial sistem $\mathrm{H}_{2}$-Alkali (Li, $\mathrm{Na}$, dan K)/grafit.

\section{Kesimpulan}

Studi interaksi grafit melalui kajian eksperimen komputasi untuk mempelajari interaksi komponen grafit sebagai materi penyimpan hidrogen dapat dengan sangat baik dilakukan menggunakan metode teori fungsi kerapatan atau DFT.

Pada penelitian terdahulu umumnya model penyimpan hidrogen dihitung dengan model terbatas yaitu model graphene serta dengan kajian interkalat yang juga terbatas, sedangkan model graphene ini adalah sangat sulit dilakukan secara eksperimen. Pada penelitian terdahulu juga masih terbatas pada kajian kemampuan mengadsorpsi molekul $\mathrm{H}_{2}$ hanya pada daerah ujung grafit. Pada disertasi ini dapat meramalkan sifat-sifat elektronik tidak hanya pada model graphene dan model ujung grafit, akan tetapi pada sistem molekul $\mathrm{H}_{2}$ dalam grafit dan dalam GICs yang bisa mewakili model graphite nanofiber. Dari hasil-hasil penelitian ini maka diharapkan dapat memahami proses penyimpanan $\mathrm{H}_{2}$ untuk media graphite nanofiber pada skala eksperimen.

Perhitungan kimia komputasi ini telah mengeksplor kemampuan model material penyimpan hidrogen dari GICs dengan menggunakan dan membandingkan ketiga atom logam alkali (Li, Na dan K) sebagai interkalatnya. Model media penyimpan hidrogen dari GICs dengan atom logam $\mathrm{Li}$ adalah model terbaik dibandingkan dengan atom logam $\mathrm{Na}$ dan $\mathrm{K}$.. 


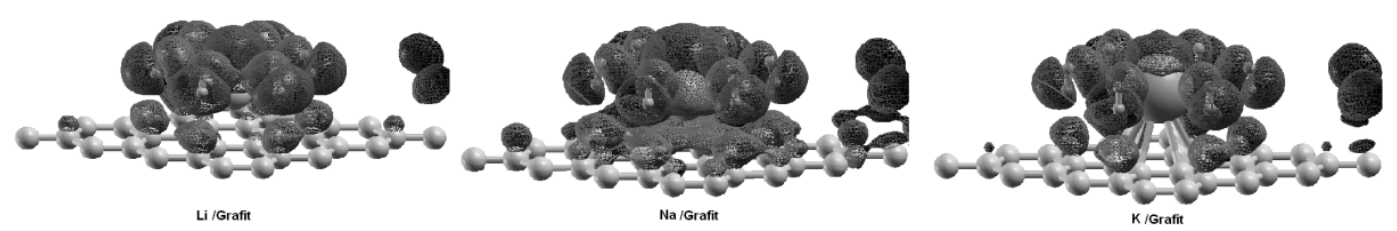

Gambar 5. Kontribusi elektron untuk sistem $\mathrm{H}_{2}$-Alkali (Li, $\mathrm{Na}$, dan K)/grafit

\section{Penghargaan}

Kami sangat berterimakasih kepada DIKTI melalui Program Sandwich untuk pendanaan penelitian ini, sehingga kami dapat menggunakan fasilitas superkomputer ini di
Kasai Laboratory, Division of Precision Science and Technology and Applied Physics, Osaka University, Osaka, Japan..

\section{Daftar Pustaka}

[1]. C. Ataca, E. Akturk, S. Ciraci, and H. Ustunel, 2008, "High-capacity hydrogen storage by metallized graphene, App. Phys. Lett., 93, pp. 043123.

[2]. DOE, Hydrogen, Fuel Cells \& Infrastructure Technologies Program: Multiyear Research, Development and Demonstration Plan: Planned program activities for 2003-2010. Chapter 3.3, Revision 1., 2005, United States Department of Energy:

[3]. H. M. Cheng, Q. H. Yang, and C. Liu, 2001, Hydrogen storage in carbon nanotubes, Carbon, 39, pp. 1447.

[4]. G. E. Froudakis, 2002, Hydrogen interaction with carbon nanotubes: a review of ab initio studies, J. Phys.: Condens. Matter, 14, R453.

[5]. M. Cobian, and J. Iniguez, 2008, Theoretical investigation of hydrogen storage in metalintercalated graphitic materials, J. Phys.: Condens. Matter, 20, pp. 285212 (11pp).

[6]. T. Yildirim, O. Gulseren, S. Ciraci, 2001, Exohydrogenated single-wall carbon nanotubes, Phys. Rev. B., 64, pp. 075404.

[7]. A. Nikitin, H. Ogasawara, D, Mann, R. Denecke, Z. Zhang, H. Dai, K. Cho, A. Nilsson, 2005, Hydrogenation of Single-Walled Carbon Nanotubes, Phys. Rev. Lett., 95, pp. 225507.

[8]. Gunawan R,, 2010, Kaltim impor batubara yang diekspor, in Press.

[9]. K. G. Dimitrakakis, E. Tylianakis, and G. E. Froudakis, 2008, Pillared Graphene: A New 3-D Network Nanostructure for Enhanced Hydrogen Storage, Nano Lett., 8(10), pp. 3166-3170.

[10]. C. Ataca, E. Akturk and S. Ciraci, 2009, Hydrogen storage of calcium atoms adsorbed on graphene: First-principles plane wave calculations, Phys. Rev. B., 79, pp. 041406 R.

[11]. I. Cabria, M. J. Lopez, and J. A. Alonso, 2008, Hydrogen storage in pure and Li-doped carbon nanopores: Combined effects of concavity and doping, J. Chem. Phys., 128, pp. 144704.

[12]. G. Kresse, and D. Joubert, 1999, From ultrasoft pseudopotentials to the projector augmentedwave method, Phys. Rev. B., 59(3), pp. 1758-1775. 
[13]. A. Kokalj, 1999, XCrySDen a new program for displaying crystalline structures and electron densities, J. Mol. Graphics Modelling, 17, pp. 176.

[14]. A. Kokalj, and M. Causa, 2003, http://www.xcrysden.org/.

[15]. T. Roman, W. A. Dino, H. Nakanishi, H. Kasai, T. Sugimoto, K. Tange, 2007, Hydrogen pairing on graphene, Carbon, 45, pp. 203-228.

[16]. D. Vanderbilt, 1990, Soft self-consistent pseudopotential in a generalized eigenvalue formalism, Phys. Rev. B., 41, pp. 7892.

[17]. J. P. Perdew, K. Burke, and M. Ernzerhof, 1996, Generalized Gradient Approximation Made Simple, Phys. Rev. Lett., 77, pp. 3865.

[18]. H. J. Monkhorst and J. D. Pack, 1976, Special points for Brillouin-zones integrations, Phys. Rev. B., 13, pp. 5188 .

[19]. F. Valencia, A. H. Romero, F. Ancilotto and P. L. Silvestrelli, 2006, Lithium Adsorption on Graphite from Density Functional Theory Calculations, J. Phys. Chem. B., 110, pp. 1483214841.

[20]. A. Lovell, F. Fernandez-Alonso, N.T. Skipper, K. Refson, S.M. Bennington, and S.F. Parker, 2008, Quantum Delocalization of Molecular Hydrogen in Alkali-Graphite Intercalates, Phys. Rev. Lett., 101, pp. 126101.

[21]. T. Suzuki, T. Hasegawa, S.R. Mukai, H. Tamon, 2003, A theoretical study on storage states of Li ions in carbon anodes of $\mathrm{Li}$ ion batteries using molecular orbital calculations, Carbon, 41, pp. 1933-1939.

[22]. O. U. Akturk and M. Tomak, 2009, $\mathrm{Au}_{n} \mathrm{Pt}_{\mathrm{n}}$ clusters adsorbed on graphene studied by firstprinciples calculations, Phys. Rev. B., 80, pp. 085417.

[23]. L. Chen, Y. Zhang, N. Koratkar, P. Jena, and S. K. Nayak, 2008, First-principles study of interaction of molecular hydrogen with Li-doped carbon nanotube peapod structures, Phys. Rev. B., 77, pp. 033405.

[24]. P. O. Lowdin, 1955, Quantum theory of Many-partcle systems. I. Physical interpretations by means of density matrices, natural spin orbitals, and convergence problems in the methods of configurational interaction, Phys. Rev., 97(6), pp. 1474-1489. 